소라페닙 치료 실패 후 소라페닙과 Tegafur 병용요법을 통해 간세포암의 완전관해를 유도한 증례 1예

황상연 $^{1} \cdot$ 이선미 ${ }^{1} \cdot$ 임정우 $^{1} \cdot$ 전기정 $^{1} \cdot$ 안상부 $^{2} \cdot$ 박진영 $^{2} \cdot$ 최철원 $^{3} \cdot$ 양광모 $^{3}$

동남권원자력의학원 ${ }^{1}$ 내과, ${ }^{2}$ 영상의학과, ${ }^{3}$ 방사선종양학과

\title{
A Case of Achieving Complete Remission with Combination of Sorafenib and Tegafur in Patients with Hepatocellular Carcinoma with Progression of Disease after Sorafenib Therapy
}

Sang Youn Hwang', Seon-Mi Lee', Jung Woo Im', Ki Jeong Jeon', Sang Bu Ahn², Jin-Young Park², Cheol-Won Choi, Kwang-Mo Yang ${ }^{3}$

Departments of ${ }^{1}$ Internal Medicine, ${ }^{2}$ Radiology, and ${ }^{3}$ Radiation Oncology, Dongnam Institute of Radiological \& Medical Sciences, Busan, Korea

Received Jan. 13, 2017

Revised Feb. 13, 2017

Accepted Feb. 13, 2017
Sorafenib is the only approved targeted agent as the first line systemic therapy for treatment of advanced hepatocellular carcinoma (HCC). However, the improvement of survival duration under 3 months is far from clinical satisfactory and most patients experience disease progression within 6 months after sorafenib therapy. Unfortunately, second line systemic therapy after treatment failure of sorafenib was not established and there were no clear guidelines for salvage treatment modalities. Recently, studies suggests that combination of sorafenib and single cytotoxic agent can be relatively effective and safe strategy that achieves promising rates of local and systemic control in advanced HCC patients. Based on above suggestions, we herein offer our experience of a case achieved complete remission by combination therapy of sorafenib and tegafur in the patient with progressed disease after sorafenib therapy. (J Liver Cancer 2017;17:88-93)

Keywords: Sorafenib; Hepatocellular carcinoma; Refractory; Cytotoxic agent; Combination

\section{서 론}

소라페닙은 진행성 및 전이성 간세포암 환자에게 유일하 게 증명된 전신치료 약제로, 2개의 무작위 대조연구를 근거 로 가이드라인에서 1차 치료제로 권고되고 있다. ${ }^{1-4}$ 하지만

\section{Corresponding author : Sang Youn Hwang}

Department of Internal Medicine, Dongnam Institute of Radiological \& Medical Sciences, 40 Jwadong-gil, Jangan-eup, Gijang-gun, Busan 46033, Korea

Tel. +82-51-720-5227, Fax. +82-51-720-5992

E-mail;mongmani@daum.net
소라페닙 사용군의 무진행 생존기간(time to progression, TTP)은 2.8-5.5개월에 불과하여 치료 효과를 지속적으로 유 지하기 힘들기 때문에, 소라페닙 치료 실패 후 구제 치료에 대한 임상적 요구가 커지고 있다. 현재까지 가이드라인에서 소라페닙 치료 실패 후 2차 치료제에 대한 권고사항은 없는 상황이며, 최근 간세포암에 관한 2차 전신요법으로 레고라 페닙에 대한 연구결과가 발표되었지만 임상에서 보편적으 로 적용되기에는 이른 상황이다. ${ }^{5}$ 따라서 실제 임상에서는 소라페닙 치료 실패 이후 세포독성화학요법으로 전환하거 나 국소치료를 재시행하는 시도가 이루어지고 있으며, 선택 된 환자에서 전신 혹은 국소치료 후에 좋은 종양 반응을 경 
험하기도 한다. 저자들은 위의 배경에 맞춰 소라페닙 치료 실패 후 소라페닙과 tegafur의 병용요법을 통해 간내암과 폐, 임파절, 복막전이의 완전관해를 이룬 증례를 경험하였 기에 이를 보고하는 바이다.

\section{증 례}

\section{1. 임상소견}

환자는 2008년 타 대학병원에서 간세포암 진단 후 2008년 2월에 간의 3번 구획절제술을 시행 받았고, 2008년 9월에 간 의 2 번 구획에 재발암이 발견되어 고주파열치료술을 시행 받았으며, 2010년 5월에 4번 구획에 재발암이 발견되어 같 은 부위에 대해서 2010년 5월과 2012년 1월에 2회의 경동맥 화학색전술(transarterial chemoembolization, TACE)을 시행 후 본원으로 전원되었다. 본원에서도 역시 같은 부위에 대 해서 2012년 7월과 12월에 2회의 TACE를 추가적으로 시행 했으나 지속적 암의 재발 및 성장을 보여 2013년 5월에 5회 에 걸쳐 총 $50 \mathrm{Gray}$ 의 정위체부방사선치료(stereotactic body radiation therapy, SBRT)를 시행 받은 후 종양의 완전관해를 이루었다. 하지만 방사선치료 1년 7개월인 2014년 12월에 다시 같은 부위에서 재발하여 2014년 12월부터 2015년 10월 까지 4회의 TACE를 추가로 시행하였다. 2015년 11월 추적 검사상 간내암의 다발성 재발을 보이고, 폐, 임파절, 복막전 이가 새롭게 발생하여 2015년 12월부터 2016년 3월까지 소 라페닙을 투여했으나 2016년 3월 추적 검사상 간내암 및 간 외 전이 모두 질병진행을 보여 다학제 진료에 의뢰되었다.

가족력상 특이 소견이 없었고, 흡연력은 없었으며, 문진 소견 및 이학적 검사에서 특이 소견은 없었다. 내원 당시 시
행한 일반혈액검사상 백혈구 $4,000 / \mu \mathrm{L}$, 혈색소 $11.6 \mathrm{~g} / \mathrm{dL}$, 혈 소판 $670,000 / \mu \mathrm{L}$ 였다. 일반화학검사상 총 단백 $7.3 \mathrm{~g} / \mathrm{dL}$, 알 부민 $3.5 \mathrm{~g} / \mathrm{dL}$, aspartate aminotransferase/alanine aminotransferase 73/65 IU/L, 총 빌리루빈 $1.5 \mathrm{mg} / \mathrm{dL}$, alkaline phosphatase $129 \mathrm{IU} / \mathrm{L}$, gamma-glutamyl peptidase $61 \mathrm{IU} / \mathrm{L}$ 였다. 혈액응고검사상 prothrombin time $56 \%$ 였으며, 종양표지자 검사상 alpha feto protein $20,814 \mathrm{ng} / \mathrm{mL}$, protein-induced by vitamin $\mathrm{K}$ antagonist (PIVKA)-II $37 \mathrm{mAU} / \mathrm{mL}$ 였고, 바이러스 간염표지자 검사상 $\mathrm{HBsAg}(+), \mathrm{HBeAg}(-)$, anti- $\mathrm{HBe}(+)$, hepatitis B virus DNA 20 IU 미만, anti-hepatitis C virus (-)였다.

\section{2. 영상 및 병리 소견}

2014년 3월 복부 단층촬영(computed tomography, CT)에 서 간의 4 번 구획에 반복적인 색전술에도 지속적 성장을 보 이는 $2.1 \mathrm{~cm}$ 크기의 동맥기 조영증강을 보이는 종괴가 관찰 되었고(Fig. 1A), SBRT 시행(Fig. 2) 1개월 후 CT에서 동맥기 에 병변의 조영증강이 소실되었으나(Fig. 1B), 1년 6개월 후 인 2014년 12월 CT에서 다시 주변부 조영증강을 보이는 재 발소견이 관찰되었다(Fig. 1C). 이후 4 회의 색전술을 추가 시행했으나 2015년 11월 CT에서 동맥기에 조영증강을 보이 는 다발성 간내종괴들(Fig. $3 \mathrm{~A}$ )이 발생하였고, 대동맥 주위 임파절(Fig. 4A) 및 복막전이(Fig. $5 \mathrm{~A}$ )가 새롭게 발생하였으 며, 흥부 CT에서 폐전이(Fig. 6A)가 새롭게 발생하였다. 이 에 2015년 12월 소라페닙 투여 후 2016년 3월 시행한 추적 $\mathrm{CT}$ 에서 동맥기에 조영증강을 보이는 다발성 간내종괴들 (Fig. 3B), 임파절(Fig. 4B), 복막전이(Fig. 5B) 및 흉부 CT에 서 폐전이(Fig. 6B) 모두 그 크기와 수가 증가한 소견을 보인 상황에서 다학제 진료에 의뢰되었다.
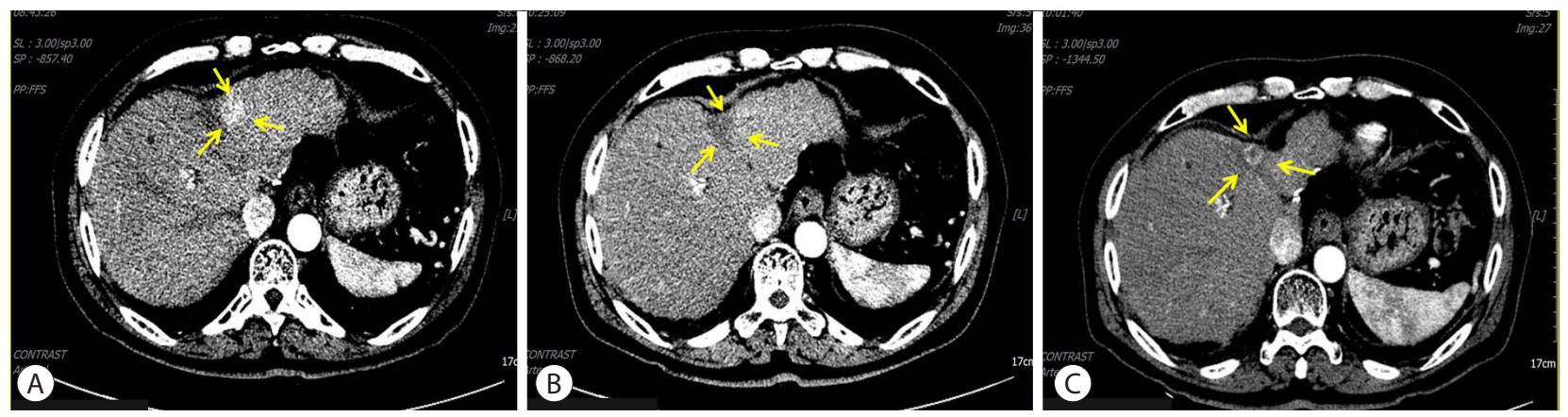

Figure 1. Liver CT during arterial phase (A-C). (A) A $2.1 \mathrm{~cm}$ sized enhancing mass was in the left lobe (arrows). (B) Previous arterial enhancement in the left lobe was disappeared and replaced as hypodense area (arrows) after SBRT. (C) A $1.0 \mathrm{~cm}$ sized mass with rim enhancement considered as recurrence was noted in the left lobe (arrows). CT, computed tomography; SBRT, stereotactic body radiation therapy. 


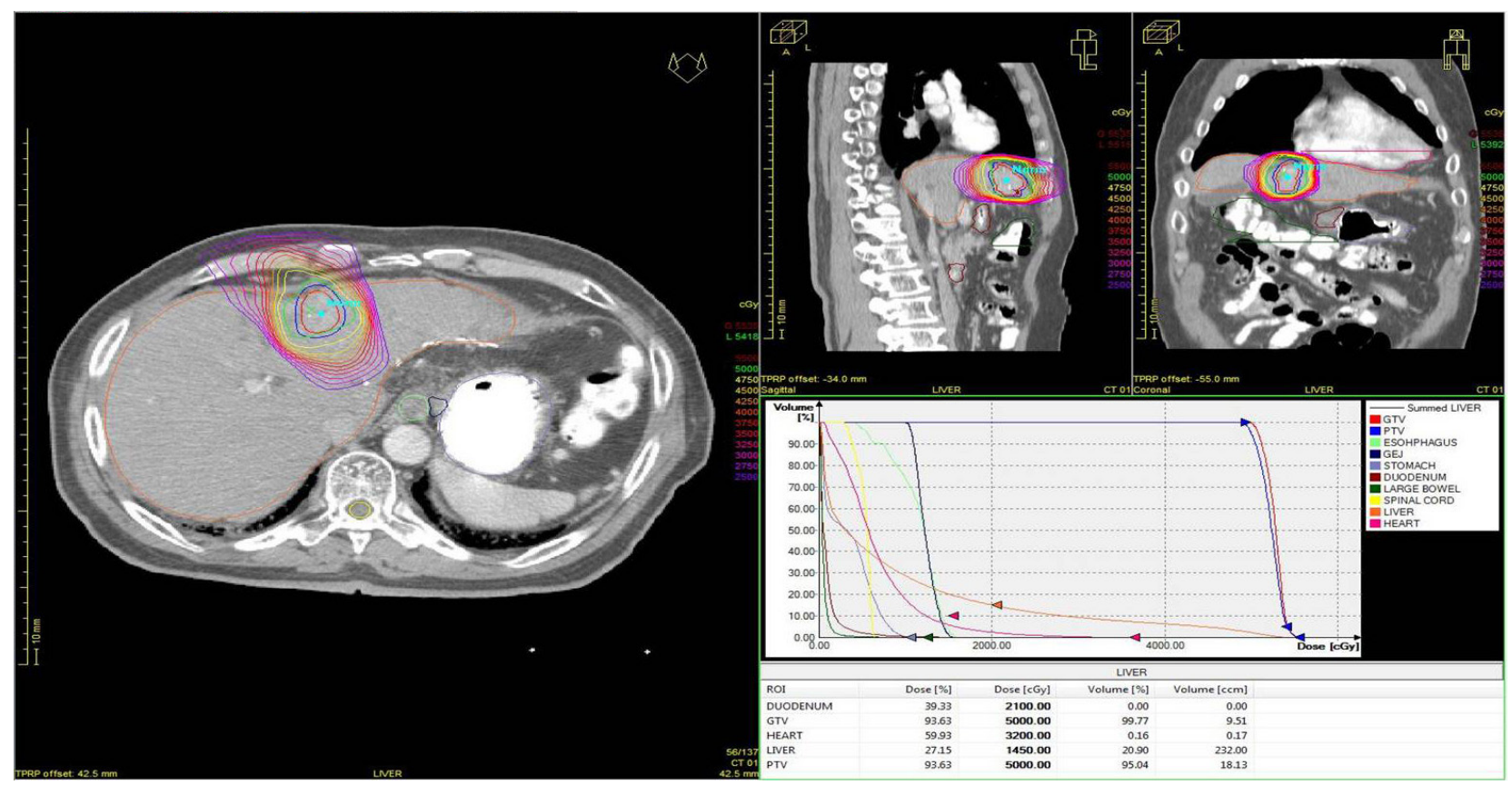

Figure 2. Simulation and planning image of stereotactic body radiation therapy.
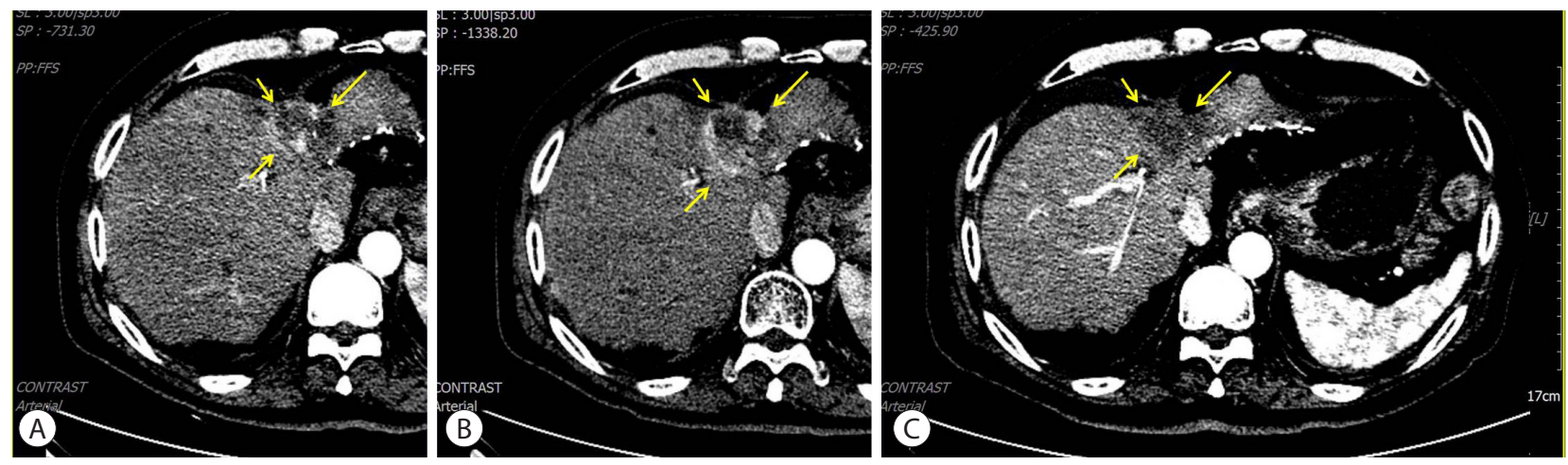

Figure 3. Liver CT during arterial phase (A-C). (A) A $2.5 \mathrm{~cm}$ sized mass with rim enhancement was in the left lobe (arrows). (B) The size of previous mass with rim enhancement was increased after sorafenib therapy (arrows). (C) Previous arterial enhancement was disappeared and replaced as hypodense area (arrows) after combination of sorafenib and tegafur. CT, computed tomography.

\section{3. 진단 및 치료경과}

영상소견에 의해 소라페닙 치료 실패로 판단하였고, 이전 간내암에 관한 반복적인 색전술 시행 후에 간내암의 파종성 진행 및 간외 전이가 유발되었던 것을 참고하여 국소치료를 시행하는 것보다는 전신요법으로 2 차 치료를 시행하기로 하였다. 하지만 혈소판 감소증이 심하고 전신상황이 양호 하지 않아 세포독성항암제의 병용은 힘들다고 판단하여 소 라페닙과 tegafur를 병용하기로 하였고, 사용한 지 6개월 후 인 2016년 8월 CT에서 동맥기에 조영증강을 보이는 다발성
간내종괴들은 더이상 조영증강 되지 않으며(Fig. $3 \mathrm{C}$ ), 임파 절(Fig. $4 \mathrm{C}$ ), 복막전이(Fig. $5 \mathrm{C}$ )는 거의 완전관해를 보이고 있고, 흉부 CT에서 폐전이(Fig. 6C) 또한 완전 관해를 보였 다. 현재까지 환자는 재발 없이 소라페닙과 tegafur를 계속 투여 중이다.

\section{고 찰}

현재 진행성, 전이성 간세포암 환자의 치료에 생존효과가 증명된 유일한 전신요법은 소라페닙이다. 하지만 가이드라 

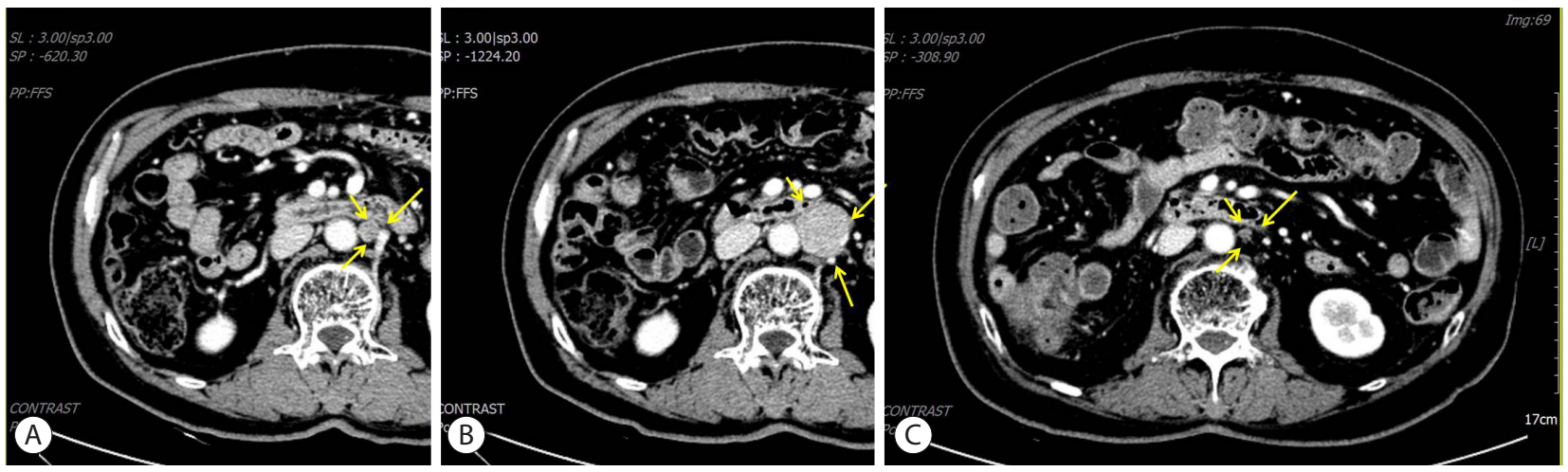

Figure 4. Liver CT during arterial phase (A-C). (A) A $1.0 \mathrm{~cm}$ sized paraaortic lymph node was noted (arrows). (B) The size of paraaortic lymph node was increased after sorafenib therapy (arrows). (C) Previous enlarged lymph node was nearly disappeared after combination of sorafenib and tegafur (arrows). CT, computed tomography.
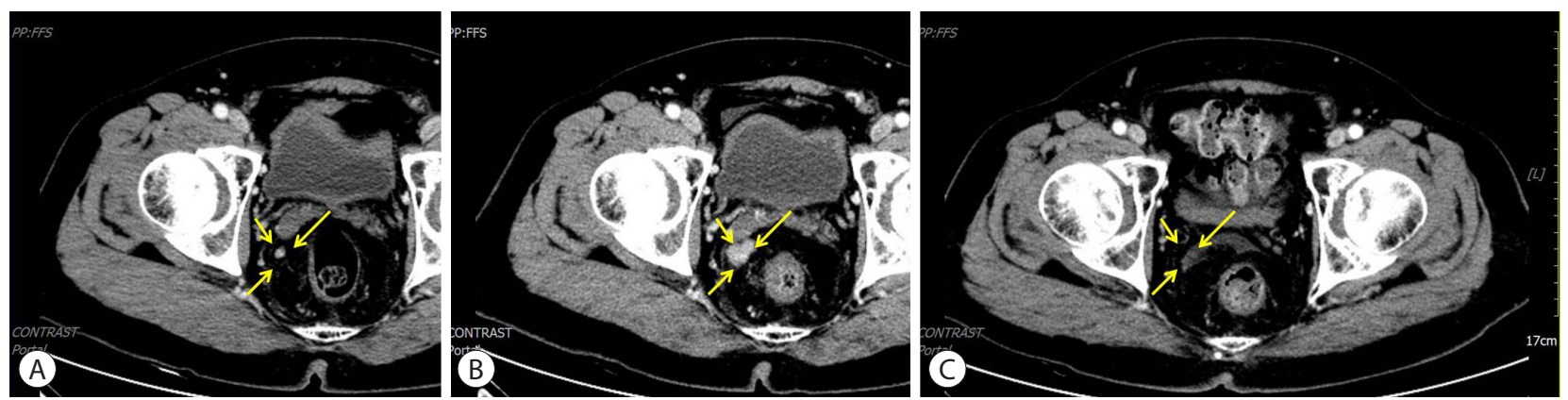

Figure 5. Liver $\mathrm{CT}$ during arterial phase (A-C). (A) A $0.5 \mathrm{~cm}$ sized peritoneal nodule was noted (arrows). (B) The size of peritoneal nodule was increased after sorafenib therapy (arrows). (C) Previous enlarged peritoneal nodule was nearly disappeared after combination of sorafenib and tegafur (arrows). CT, computed tomography.
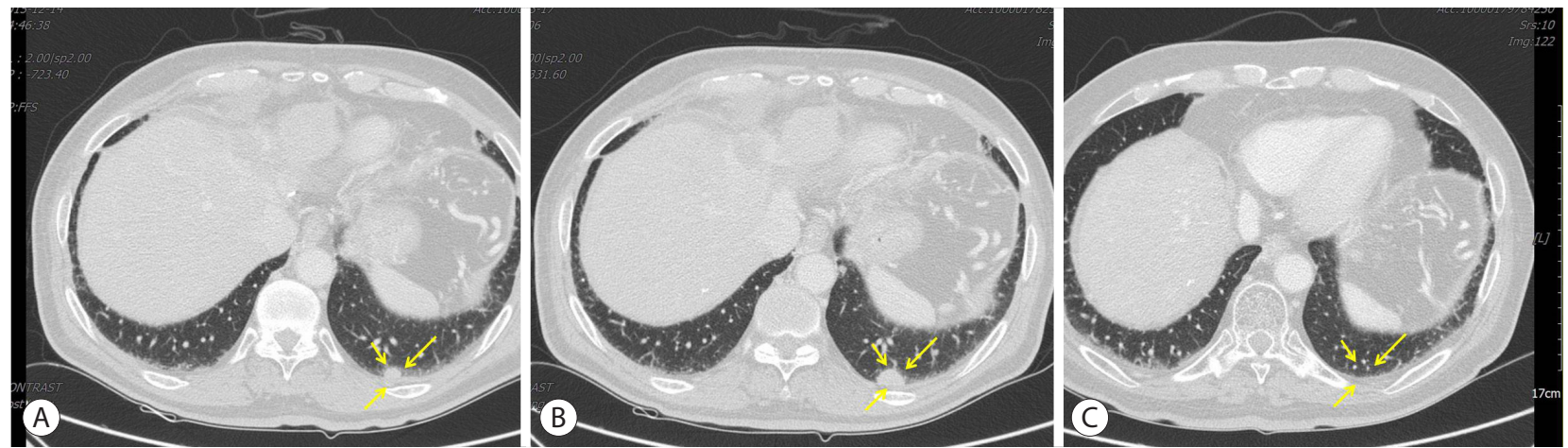

Figure 6. Chest CT findings. (A) A $1.0 \mathrm{~cm}$ sized lung nodule was noted in the left lower lobe (arrows). (B) The size of lung nodule was increased after sorafenib therapy (arrows). (C) Previous enlarged lung nodule was nearly disappeared after combination of sorafenib and tegafur (arrows). $\mathrm{CT}$, computed tomography.

인의 근간이 된 두 개의 무작위 대조연구에서 보고한 소라 페닙군의 중앙생존기간(median survival, MS)은 Asia-Pacific (AP) trial과 Sorafenib Hepatocellular Carcinoma Assessment Randomized Protocol (SHARP) trial에서 각각 6.5개월, 10.7 개월로 위약군의 4.2 개월, 7.9 개월에 비해 2-3개월 정도의 추
가적 생존연장을 보였고, TTP는 2.8 개월, 5.5 개월에 불과하 여 실제 임상적 요구에 다소 못 미치는 상황이다. ${ }^{1,2}$ 또한 전 향적 대규모 관찰연구였던 Global Investigation of therapeutic DEcision in hepatocellular carcinoma and Of its treatment with sorafeNib (GIDEON) study에 참여하였던 한국에 있는 
11 개 병원의 497 명의 환자만을 대상으로 분석했을 때, MS 8.5 개월, TTP 2.5 개월로 보고하였고, 종양조절률(disease control rate, DCR)은 29.38\% (complete response [CR] $0.61 \%$, partial response [PR] 2.04\%, stable disease [SD] $26.73 \%$ )로 $\mathrm{AP}$ trial의 $57.3 \%$ (CR 0\%, PR 3.3\%, SD 54\%)와 SHARP trial의 $73 \%$ (CR 0\%, PR 2\%, SD 71\%)에 비해 훨씬 불량한 임상 성적을 보고하였다. ${ }^{6}$ 이처럼 소라페닙은 종양 조절효과가 크지 않으며, 지속적으로 사용하기 힘들기 때문 에 소라페닙 치료 실패 후 2차 치료에 대한 임상적 고민이 증가되고 있는 상황이다.

따라서 실제 임상에서는 소라페닙 치료 실패 후 전신치료 가 필요한 상황에서 세포독성화학요법을 2차 치료로 선택 하게 된다. Doxorubicin (DOXO)은 오랜 기간 동안 간세포 암의 세포독성화학요법의 근간을 이루었는데, 다른 전신요 법과 비교한 소수의 무작위 조절 3상 연구에서 $\mathrm{DOXO}$ 의 종 양반응률(response rate [RR]; CR + PR)은 2.7-10.5\%, MS 5-7.4개월로 보고하였고, 실험군의 치료 성적을 볼 때 PIAF (cisplatin, interferon, DOXO, 5-FU [fluorouracil])의 경우 RR 20.9\%, MS 8.7개월, FOLFOX (5-FU, leucovorin, oxaliplatin) 4 의 경우 RR $8.2 \%$, MS 6.4개월로 DOXO 단독치료에 비해 약간의 차이가 있어 보이지만 통계적 유의성은 없다고 보고하였다. 세포독성화학요법을 2차 요법으로 시행한 연 구는 드문데, 국내의 단기관 소규모의 후향적 연구에서 소 라페닙 치료 후 질병진행을 보이는 31 명의 환자를 대상으로 epirubicin (50 mg/m $/ \mathrm{m}^{2} \mathrm{IV}$; day 1$)$, cisplatin $\left(60 \mathrm{mg} / \mathrm{m}^{2} \mathrm{IV}\right.$; day 1), 5-fluorouracil (FU) (1,000 mg/m² IV; day 1-3)를 병합하 여 사용했을 때 DCR 45.2\% (PR 12.9\%, SD 32.3\%), MS 7.8 개월, TTP 2.7 개월로 비교적 고무적인 치료결과를 발표하 였으나 grade 3,4 의 혈액독성(혈소판 감소증 $27.4 \%$, 백혈구 감소증 $53.9 \%)$ 이 비교적 흔하게 발생하여 임상적 사용에 주 의를 요한다. ${ }^{8}$

본 증례에서는 소라페닙과 tegafur와의 병합을 통해 좋은 종양반응을 경험하였는데, 이와 같이 소라페닙과 단일 세포 독성약제와의 병합은 아래의 몇 가지 점에서 소라페닙 실패 후 비교적 좋은 2 차 치료로서의 가능성이 있다. 첫째는 단일 세포독성약제의 경우 병합화학요법의 부작용인 골수억제 가 상대적으로 경할 가능성이 있다. 둘째는 소라페닙과 세 포독성약제와의 병합을 통해 각 약제의 세포살상능력을 증 가시키거나 각 약제의 내성의 완화시킬 가능성이 있다. 실 제 국외의 다국적 2 상 무작위 조절 연구에서 96 명의 진행성 간세포암 환자를 소라페닙과 DOXO $\left(60 \mathrm{mg} / \mathrm{m}^{2}\right.$ every 3 weeks) 병합요법군 47명, DOXO 단독치료군 49명으로 나누 어 연구를 진행한 결과 각 군의 MS는 13.7 개월, 6.5 개월이었 고, TTP는 6.0 개월, 2.7 개월로 병합군에서 DOXO 단독군에 비해 통계적으로 의미있는 생존증가를 보였으며, 두 군 간 에 약제독성은 크게 차이가 없다고 하였다.

그 기저 기전으로 DOXO와 같은 anthracycline 약제는 암 세포의 stress mediated apoptosis를 유발하는데, 이것에 저 항하는 기전으로 endothelial cell의 Raf-1 dependent basic fibroblast growth factor mediated protection이 대표적인데, 공 교롭게도 소라페닙이 Ras/Raf/MEK/ERK pathway를 억제함 으로 $\mathrm{DOXO}$ 의 내성기전의 극복에 기여하여 세포살상효과 를 증가시킬 수 있다고 제시하였다. 또한 대만의 다기관 2 상 연구에서 53 명의 진행성 간세포암 환자에게 소라페닙과 tegafur $\left(125 \mathrm{mg} / \mathrm{m}^{2}\right.$ twice per day continuously)를 병합한 결 과 MS 7.4개월, TTP 3.7개월을 보였고, DCR 57\% (CR 0\%, $\mathrm{PR} 8 \%, \mathrm{SD} 49 \%$ )였는데, 같은 지역인 대만에서 이루어졌던 AP trial의 MS 6.5개월, TTP 2.8 개월에 비해 동등이상의 결 과를 보고하였고, 그 기저 기전으로 metronomic tegafur가 activated endothelial cell의 proliferation을 억제하고, bone marrow로부터 endothelial projenitor cell의 mobilization을 억제하며, 여러 anti-angiogenic factor들을 유도하여 소라페 닙에 synergistic한 효과를 보인다고 하였다. ${ }^{10}$ 또한 동물실험 에서 metronomic tegafur와 소라페닙과의 병용을 통해 소라 페닙 내성발생시점을 지연시키는 결과를 보고하기도 하였 다. ${ }^{11}$ 비록 언급한 두 가지 임상연구가 소라페닙 치료 실패 환자를 대상으로 소라페닙과 세포독성약제와의 병용요법 을 시행한 경우는 아니지만 기존에 보고된 소라페닙 단독 치료군에 비해 좋은 성적을 보이고 있어 2 차 치료요법으로 서의 가능성이 있을 것으로 생각된다.

최근 소라페닙 투여 후 질병의 진행을 보이는 573 명의 환 자를 대상으로 레고라페닙을 투여 받은 379명과 위약을 투 여 받은 194명의 임상연구결과가 발표되었는데, 레고라페 닙군과 위약군의 MS는 각각 10.6 개월, 7.8 개월(hazard ratio $0.63)$ 로 레고라페닙군에서 추가적 생존향상을 보인다고 하 였다. 또한 레고라페닙군에서 $65 \%$ 의 DCR (CR 1\%, PR $10 \%, \mathrm{SD} 54 \%)$ 을 보이면서도 grade 3, 4 의 부작용은 고혈압 (15\%), 손발증후군(13\%), 피로감(9\%), 설사(3\%)로 대장암 혹은 위장관 간질종양에서 레고라페닙 사용 시 있었던 부작 용에 비해 큰 차이가 없음을 발표하여 비교적 안전하고도 효과적으로 쓸 수 있는 2 차 약제임을 보고하였다. 다만 약 제 부작용으로 $68 \%$ 의 환자에서 용량을 감량하거나 일시 중 
지했고, $25 \%$ 의 환자에서 치료를 중단해야 했으며, $2 \%$ 의 환 자에서는 약제투여와 관련된 합병증으로 사망한 것으로 보 고하여 신중한 사용이 필요할 것으로 보인다. 또한 위약군 에 비해 2.8 개월 정도의, 임상적 기대에 다소 못 미치는 생존 연장효과를 보였고, 레고라페닙 투여 전 소라페닙 투여의 평균기간이 7.8개월(4.2-14.5개월)로 소라페닙 투여에 비교 적 tolerable 하거나 초기 치료반응, 즉 3 개월 사용 후 반응평 가 시 종양조절이 되었던 환자들을 연구대상으로 했을 가 능성이 있기 때문에 실제 약제 부작용으로 소라페닙을 충분 한 기간 동안 복용하지 못하거나, 복용했음에도 첫 3 개월 안에 질병의 진행을 보이는 환자들에게 레고라페닙이 어느 정도의 효과를 지닐지에 대해서는 향후 연구가 필요하며, GIDEON study와 같은 worldwide real life data를 기다려 보 는 것이 필요할 것으로 생각된다. ${ }^{5}$

결론적으로 이 증례는 반복적인 색전술 후 지속적 간내 암이 진행되고, 폐, 임파절, 복막전이가 새롭게 발생하는 환 자에서 소라페닙 사용 후 간내암과 간외전이 부위 모두 진 행하는 치료 실패를 경험한 후 소라페닙과 tegafur의 병용요 법을 통해 간내암과 간외전이의 완전관해를 유도한 증례이 다. 1차 치료로서 소라페닙에 불응성인 환자에서 소라페닙 과 부작용이 적은 단일 세포독성항암제의 병합요법을 통해 치료성적을 개선시킬 수 있을 것으로 기대되며 이에 대한 추가 연구가 필요하다고 하겠다.

\section{Conflicts of Interest}

The authors have no conflicts to disclose.

\section{REFERENCES}

1. Llovet JM, Ricci S, Mazzaferro V, Hilgard P, Gane E, Blanc JF, et al. Sorafenib in advanced hepatocellular carcinoma. N Engl J Med 2008:359:378-390.

2. Cheng AL, Kang YK, Chen Z, Tsao CJ, Qin S, Kim JS, et al. Efficacy and safety of sorafenib in patients in the Asia-Pacific region with advanced hepatocellular carcinoma: a phase III randomised, doubleblind, placebo-controlled trial. Lancet Oncol 2009;10:25-34.

3. European Association for Study of Liver; European Organisation for Research and Treatment of Cancer. EASL-EORTC clinical practice guidelines: management of hepatocellular carcinoma. Eur J Cancer 2012;48:599-641.

4. Bruix J, Sherman M; American Association for the Study of Liver Diseases. Management of hepatocellular carcinoma: an update. Hepatology 2011;53:1020-1022.

5. Bruix J, Qin S, Merle P, Granito A, Huang YH, Bodoky G, et al. Regorafenib for patients with hepatocellular carcinoma who progressed on sorafenib treatment (RESORCE): a randomised, double-blind, placebocontrolled, phase 3 trial. Lancet 2017;389:56-66.

6. Kim DY, Kim HJ, Han KH, Han SY, Heo J, Woo HY, et al. Real-life experience of sorafenib treatment for hepatocellular carcinoma in Korea: from GIDEON data. Cancer Res Treat 2016;48:1243-1252.

7. Asghar U, Meyer T. Are there opportunities for chemotherapy in the treatment of hepatocellular cancer? J Hepatol 2012;56:686-695.

8. Lee JE, Bae SH, Choi JY, Yoon SK, You YK, Lee MA. Epirubicin, cisplatin, 5-FU combination chemotherapy in sorafenib-refractory metastatic hepatocellular carcinoma. World J Gastroenterol 2014;20:235-241.

9. Abou-Alfa GK, Johnson P, Knox JJ, Capanu M, Davidenko I, Lacava $J$, et al. Doxorubicin plus sorafenib vs doxorubicin alone in patients with advanced hepatocellular carcinoma: a randomized trial. JAMA 2010;304:2154-2160.

10. Hsu CH, Shen YC, Lin ZZ, Chen PJ, Shao YY, Ding YH, et al. Phase II study of combining sorafenib with metronomic tegafur/uracil for advanced hepatocellular carcinoma. J Hepatol 2010;53:126-131.

11. Tang TC, Man S, Xu P, Francia G, Hashimoto K, Emmenegger U, et al. Development of a resistance-like phenotype to sorafenib by human hepatocellular carcinoma cells is reversible and can be delayed by metronomic UFT chemotherapy. Neoplasia 2010;12:928-940. 